\title{
Review of the losses and devastation caused by corrosion in the Nigeria oil industry for over 30 years
}

\author{
A.I. Obike, ${ }^{1} *$ K.J. Uwakwe, ${ }^{2,3}$ E.K. Abraham, ${ }^{1}$ A.I. Ikeuba ${ }^{2,4}$ \\ and W. Emori ${ }^{5,6}$ \\ ${ }^{I}$ Department of Pure and Industrial Chemistry, Abia State University, P.M.B. 2000, Uturu, \\ AbiaState, Nigeria \\ ${ }^{2}$ Department of Pure and Applied Chemistry, University of Calabar, Calabar, 1115, \\ Nigeria \\ ${ }^{3}$ State Key Laboratory of Catalysis, Dalian Institute of Chemical Physics, CAS, Dalian \\ 116023, PR China \\ ${ }^{4}$ CAS Key Laboratory of Nuclear Materials and Safety Assessment, Institute of Metal \\ Research, Chinese Academy of Sciences, Shenyang 110016, PR China \\ ${ }^{5}$ School of Materials Science and Engineering, Sichuan University of Science and \\ Engineering, Zigong 643000, PR China \\ ${ }^{6}$ Key Laboratory of Material Corrosion and Protection of Sichuan Province, Zigong \\ 643000, PR China \\ *E-mail:ai.obike@abiastateuniversity.org.ng
}

\begin{abstract}
Pipeline failures have been linked majorly to corrosion caused by aging infrastructure. Most of the pipelines installed to transport petroleum products in Nigeria are over sixty years old. In the 35 years under review, Nigeria has had about 7,359 incidences of spills resulting in the release of 3,114,255 barrels, estimated at $\$ 247,957,000$. This translates to an average of over 600 spills per year, the highest rate of spills globally. Records indicated that 6\%, 25\% and $69 \%$ respectively of the total oil spilled in Nigeria occurs on land, swamp and offshore environments. Several millions of Dollars have been lost as a result of corrosion and the inefficiency of corrosion management. Underlining the dangers of oil spillage, environmentalist urged the Federal Government to declare a state of emergency on oil spills and the affected areas. They stressed that it is a silent killer of Nigeria's future, as it posses grave danger to lives and properties of people. Nigeria is home to about 150 species of fish and other wildlife that remain endangered by spills. Maintenance of older pipelines can be very difficult but crucial in minimizing loses. The cost of corrosion control within the year 2004-2008 was found to be far less compared to the estimated cost of oil spillage in 1978 alone, which is over $\$ 38$ billion; prevention is really better than cure. Enforcement and strict adherence to legislation and government policy on minimum standards created to management corrosion could be key to prevent further losses.
\end{abstract}

Keywords: corrosion, pipeline, mild steel, oil spill, corrosion cost. 


\section{Introduction}

Since the commercial production of the Nigerian crude oil began in 1958, pipelines have been considered a safe form for the transportation of petroleum and other crude oil products. However, the nation has recorded tragic losses due to pipeline failures. Hopkins (2008) reported that pipeline maintenance and management, as well as pipeline materials design and operation, are the basic factors to consider in ensuring the safety of pipelines. If these factors are compromised, then pipeline failures become inevitable.

The causes of pipeline failures differ from region to region. Seam welds, corrosion, and theft are reported as the basic causes of pipeline failures in China, while the US Department of Transportation's Research and Special Programs Administration, Office of Pipeline Safety (PSPA/OPS) reported the following as the basic causes of pipeline failures in the US: excavation, natural processes, third party factors, weld failures, equipment failures, operations, and corrosion. Furthermore, the report singled out corrosion as the largest contributor to pipeline failures when considering only hazardous liquid pipeline data (Hopkins, 2008). In Nigeria, several studies identified mechanical failures, corrosion, and third-party activities/sabotage as the major causes of pipeline failures. The others being operational errors and natural hazards (Nwiloet et al., 2000; Isirimahet et al., 2006; Achebe et al., 2012). Irrespective of the region under study, corrosion has gained a growing attention as one of the leading causes of pipeline failures in the world.

Corrosion can be defined in many ways, some definitions are very narrow and deal with a specific form of corrosion, while others are quite broad and cover many forms of deterioration. The word corrosion is derived from the Latin word corrodere, which means "to gnaw to pieces" The general definition of corrosion is to "eat into" or "wear away" gradually, as if by gnawing. Corrosion is the deterioration of a material (usually metal) and/or its properties because of the reactions with its environment. It occurs as a result of oxidation (wearing away), and when the metal is in contact with oxygen (from the atmosphere) and water, the resultant oxide(s) coats the metal (Ozumba.1997). This is an electrochemical process which leads to the deterioration of a material and its properties. The environment consists of the entire surrounding in contact with the material. The primary factors used to describe the environment include the following: physical state: gas, liquid, or solid; chemical composition: constituents and concentrations; and temperature. Other factors can be important in specific cases. Examples of these factors are the environmental factor, the age of pipes, the relative velocity of a solution and mechanical loads on the material, including residual stress within the material. The environment is air saturated seawater. The corrosion behavior of a material cannot be described and managed unless the environment in which the material is to be exposed to is specified. Similarly, the aggressiveness of an environment cannot be described unless the material that is to be exposed to that environment is identified. In summary, the corrosion behavior of the material depends on the environment to which it is subjected, and the aggressiveness of an environment depends on the material exposed to that environment. 
The swath environmental loses and devastation prevailing in the oil and gas industry necessitates the appropriate and cost-effective materials choice and corrosion control measures. The implementation of these measures is becoming more important as the scar of corrosion on safety, economy and the environment takes up more challenging roles in Nigeria. Furthermore, production conditions tend to become more corrosive hence requiring a more effective corrosion control management strategy. Corrosion related failures constitute over $25-45 \%$ of failures experienced in the oil and gas industry in Nigeria. More than half of these failures are associated with sweet $\left(\mathrm{CO}_{2}\right)$ and sour $\left(\mathrm{H}_{2} \mathrm{~S}\right)$ producing fluids. Records and analysis of failures of piping systems ascertained during the 1980s till date in the oil and gas industry in Nigeria showed the degree of damage caused by corrosion and other types of materials degradation (Kermani and Harrop, 1996). It is plain and distinct that corrosion enforces a remarkable cost penalty on the choice of material at the design stage and its possible occurrence also has serious safety and environmental implications (Kermani and Harrop, 1996). Corrosion has some wide range implications on the integrity of materials used in the petroleum industry. The corrosion of pipelines and tanks can be said to account for $50 \%$ of all the spills, hence the largest contributor to the total number of oil spills in the Niger Delta. The Pipeline corrosion leads to rupturing or leaking of production infrastructures (Nwilo and Badejo, 2001). Studies by Umezurike (1999) shows that if adequate protective measures are not taken, oil transportation facilities such as pipelines, flow lines, and storage tanks (vessels) lose their thickness and result in ultimate failure within a few decades.

\section{Corrosion in Nigeria for the past 30 years}

Corrosion challenge in Nigeria for over three decades is an outstanding problem in the oil and gas industry. Engineers and designers must consider the effect of corrosion on the lifespan of the equipment used in the oil and gas industry. Reports showed that some oil companies had their pipeline ruptured due to corrosion, resulting in oil spills which created environmental losses and devastation. Resources are lost in cleaning up this environmental mess, large-scale ecological harm resulted from corrosion effects, especially in the Niger Delta area. The possibility of occurrence of corrosion in an industrial plant has posed a lot of concern to petroleum, chemical, and mechanical engineers as well as chemists in Nigeria. Mechanical engineers and chemists in Nigeria discovered that corrosion could have some effects on the chemistry of a chosen process, and corrosion could affect reaction and alter the purity of the reaction products (Adindu et al., 2013).

Some catastrophic incidents which resulted from corrosion failures include

- Bonga Offshore Field Shell Petroleum Development Company (SPDC) failure on December 20, 2011, in which estimated 40,000 barrels of oil were spilled.

- World Oil online (2012) reported that this occurred during a routine tanker loading operations. 
A United Nation Development Programme (UNDP) report in 2006 stated that there was a total of 6,817 oil spills between 1976 and 2001 which accounted for a loss of 3 million barrels of oil, of which more than $70 \%$ was not recovered. The record indicated that $6 \%, 25 \%$ and $69 \%$ respectively of the total oil spilled in the Niger delta occurs on land, swamp and offshore environments. 1997-2001 recorded a total number of 2,097 oil spill incidents in Nigeria (Niger Delta). Unueroh et al., 2016 revealed that the Nigerian National Petroleum Corporation (NNPC)/Pipelines and Product Marketing Company (PPMC) carried out a case study on 2A pipeline which stretches from Warri pump station to Benin Oil Depot. The 2A pipeline length is $89.9 \mathrm{~km}$ and it is made of carbon steel. The pipeline was analyzed and the types of corrosion found were; pitting, microbial, sulfidestress cracking and hydrogen-stress cracking. These were caused by poor maintenance and management of the pipeline system, sever mutilation of the pipeline coating, substrate due to sequential vandalization and coating failure. The $2 \mathrm{~A}$ pipeline was analyzed using the cathodic protection control method and it was deduced that about $10.3 \mathrm{~km}$ of the pipeline was well protected and sound to be used but about $62.7 \mathrm{~km}$ experienced under protection, which meant that the probability of corrosion infestation was high within a very short period of time and finally $16 \mathrm{~km}$ of the pipeline experienced corrosion.

Nigeria's oil-rich Niger Delta region is characterized by a prevalence of both old and new oil spills, that is, over 9,343 incidents in the last 10 years according to official records. This translates to an average of nearly a thousand spills per year, the highest rate of spills globally.

Official records from the NationalOil Spill Detection and Response Agency (NOSDRA) covering the period from 2006 to 2015 indicates that there were over 5,000 spillage sites from the over 9,000 spills (Kalejaye, 2015). Some of the spill sites, according to the records, include:

- Forcados terminal tank failure in 1978 of about 580,000 barrels (Nwilo and Badejo, 2001).

- 6 Taylor Creek 2S flowline near TK 1T well location, 8 Nkpoku-Bomu Trans Niger pipeline right of way B.

- 28 Trans Niger pipelines at Ekporo,18Tebidaba/Brass pipeline at Oyeregbene; 24 Nembe Creek Trunkline, NCTL, at Adamakri and Osie65 flowline wellhead location Oshie.

- 18 Tebidaba/Brass pipelines at Oyeregbene, 28" Nkpogu-Bomu Pipeline-Kporgor Tai LGA River State, 18 Tebidaba/Brass pipelines at Oyeregbene 16, and many more.

French oil giant, Total, reported an incident at its Obagi-Rumuekpe export line in Rivers State, which it blamed on sabotage. The company did not say the volume of oil spilled but maintained that it lost up to 100,000 barrels of oil per day due to the closure of the export line following the spill (Kalejaye, 2015). 


\section{Quantification of the losses and devastation caused by corrosion in Nigeria}

One of the many hundreds of 40-year-old pipelines across the Niger delta had corroded and spilled oil for several years (Vidal, 2010). According to Nigerian Federal Government figures, there were more than 7,000 spills between 1970 and 2000, and there are 2,000 official major spillages sites, many going back decades, with thousands of smaller ones still waiting to be cleaned up. More than 1,000 spill cases have been filed against Shell alone. Shell admitted to spilling 14,000 tons of oil (Nwilo and Badejo, 2008), which is approximately 98,000 barrels with an estimated cost of about $\$ 7.8$ million worth of oil in 2009. Industrial catastrophes in Nigeria have it that many industries have lost several billions of Naira and millions of Dollars as a result of corrosion and the inefficiency of corrosion management.

The Federal Government of Nigeria fined SPDC \$5 billion for the effects of the spill. The heaviest recorded spill so far occurred between 1979 and 1980 with a net volume of $694,117.13$ barrels with an estimated worth of $\$ 55.2$ million and 600,511.02 barrels with an estimated worth $\$ 47.8$ million worth of oil respectively. According to the Department of Petroleum Resources (DPR) as reported by Vidal (2010) and Daily Independent (2010), an estimated volume of 1.89 million barrels worth $\$ 140$ million of crude oil was spilled into the Niger Delta environment between 1976 and 1996 out of a total of 2.4 million barrels spilled in 4,835 incidents with estimated worth of over $\$ 190$ million.

Bonga facility, which spilled 40,000 barrels of oil worth above \$3.1 million into the environment, and for which NOSDRA has ordered the multinational oil company to pay $\$ 3.6$ billion Naira to the affected communities. Commenting on the spill record as revealed by NOSDRA, Professor John Onwuteaka of the Department of Applied and Environmental Biology at the Rivers State University of Science and Technology, Port Harcourt, said that lack of any openly documented access to spillage sites or spills predating 2006 increases the assumption of many undocumented sites waiting to be detected. The over 9,000 spill incidents as reported by NOSDRA, according to environmentalist, would lead to Nigeria losing nine states that make up the oil-rich region, including their arable lands and water resources in the future if drastic measures are not taken to stop the menace of spills in the region (Kalejaye, 2015). Underlining the dangers of oil spillage, environmentalist present at the $4^{\text {th }}$ Oil Spill Conference 2015, organized by Kaku Professional Engineers Ltd. in Lagos, urged the Federal Government to declare a state of emergency on oil spills and the affected Niger Delta regions. They also urged the government to commence immediate cleanup of all spill sites, stressing that it is a silent killer of Nigeria's future (Kalejaye, 2015). Nigeria's oil wealth flows back into the poverty-stricken Delta. The Delta itself, some 51,800 sq.km $(20,000$ square miles) of wetlands in southern Nigeria, is home to about 150 species of fish

and other wildlife that remain endangered by spills. Shell also was accused in a US lawsuit of playing a role in the 1995 executions of activist Ken Saro-Wiwa and other civilians by Nigeria's former military regime. Shell reached a $\$ 15.5$ million settlement to end the lawsuit in June but acknowledged no wrongdoing (Nwilo and Badejo, 2008). Figures 1, 2 and 3 
show the number of incidents, volume spilled in barrels and the estimated worth of oil spills in dollars in corrosion-related cases for thirty-six (36) years. These show how much supposed generated revenues have been lost as a result of corrosion on the pipelines leading to oil spills.

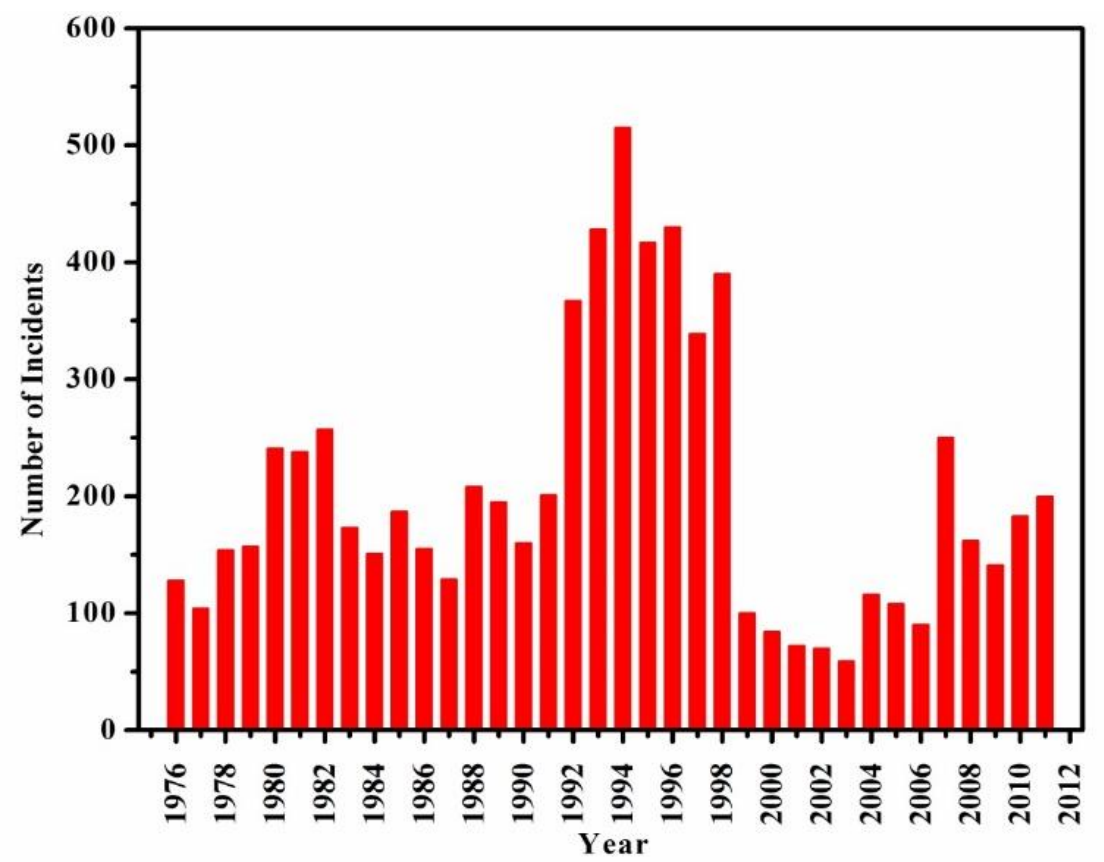

Figure 1. Number of oil spill incidents from 1976 to 2011 (Nwilo and Badejo, 2008; Adindu et al., 2013).

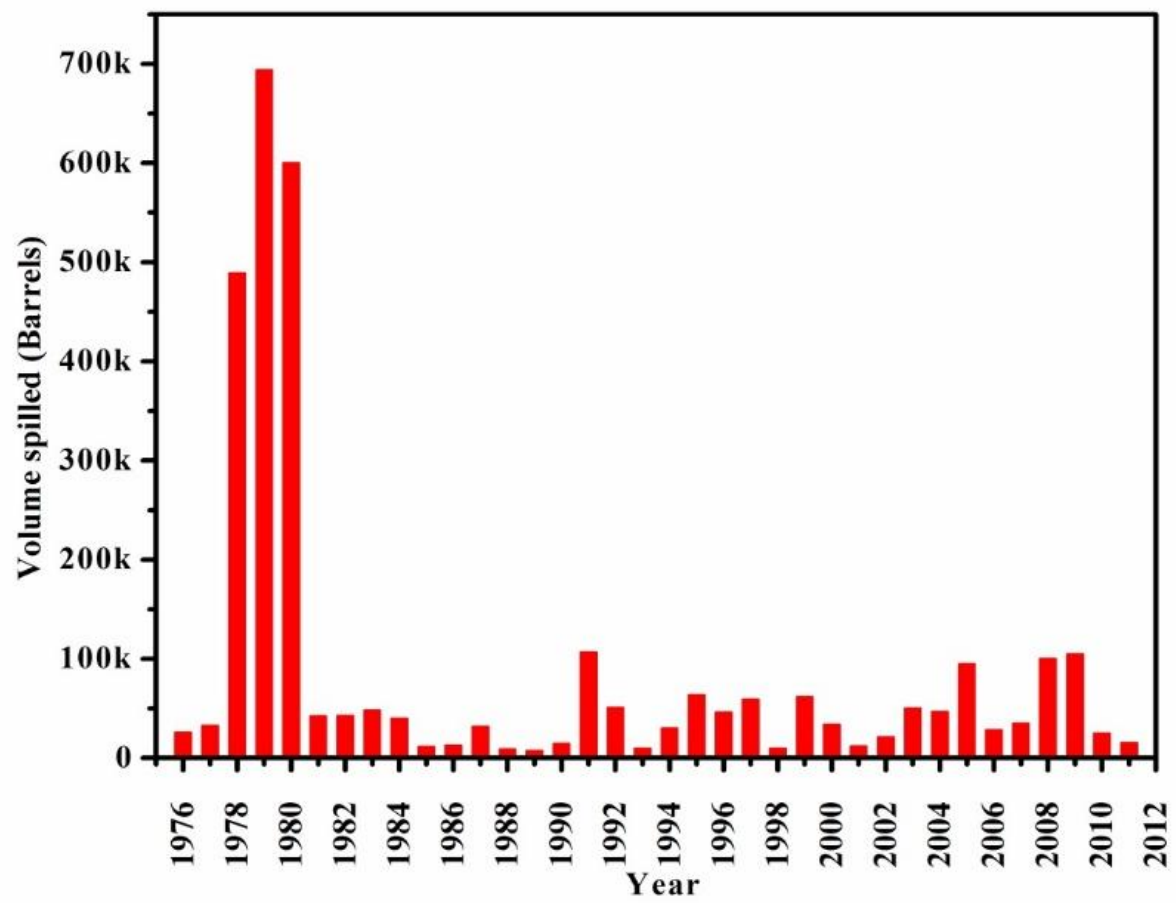

Figure 2. Volume Spilled in barrels from 1976 to 2011 (Nwilo and Badejo, 2008; Adindu et al., 2013). 


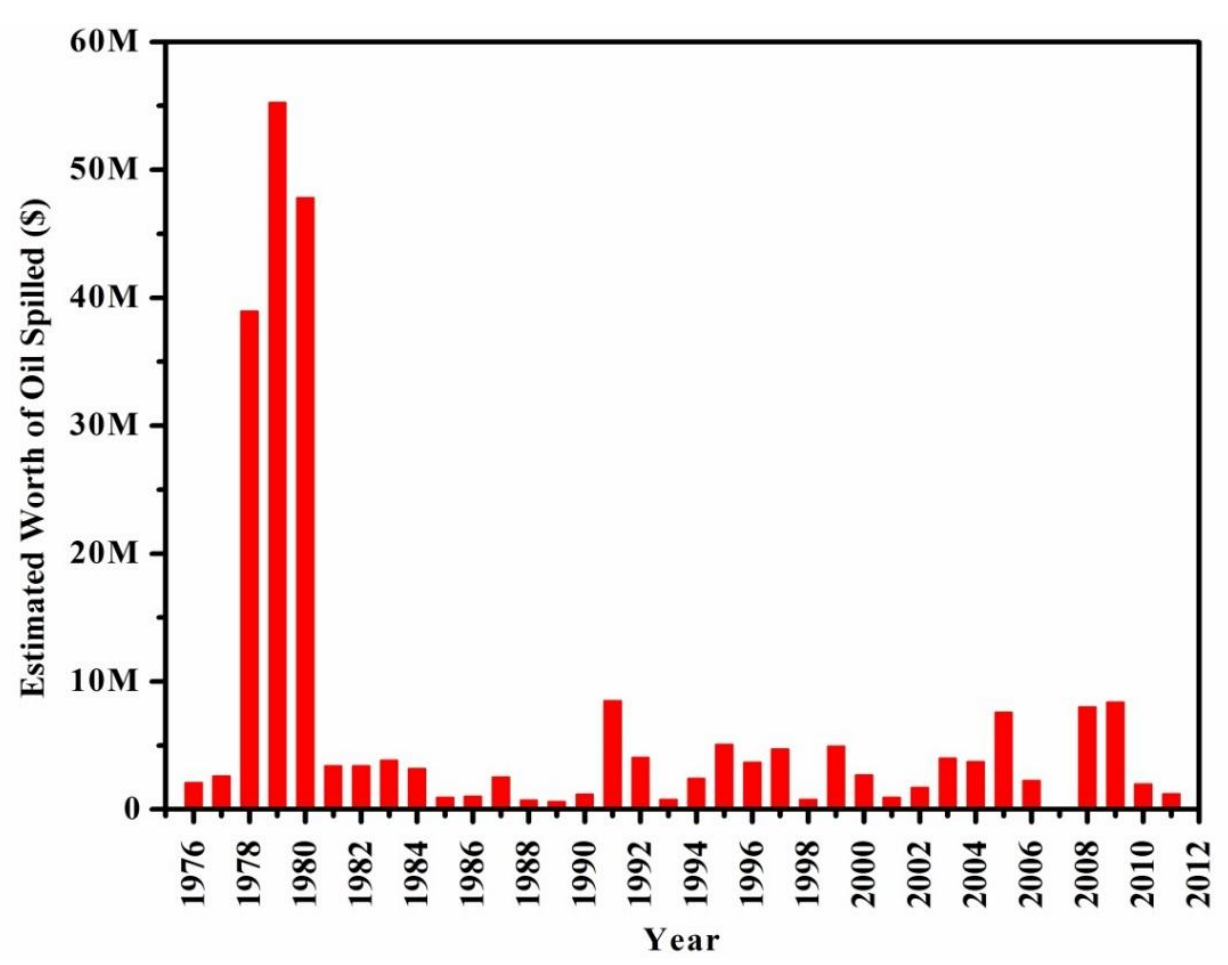

Figure 3. Estimated worth of oil spilled in Dollars (\$) from 1976 to 2011 (Nwilo and Badejo, 2008; Adindu et al., 2013).

Akinyemi et al., 2012 obtained data from an onshore oil production platform in South-Eastern Nigeria through interview from the Production Engineer, Production Chemist, Maintenance Engineer and some workers directly involved in carrying functions that may results in corrosion. Data collected include records of failure, maintenance records, deferment records, asset replacement records, frequency of repair activities and their corresponding cost. Other information obtain include corrosion prevention methods such as coating, chemical treatment, cathodic protection, cleaning, pigging and the corresponding cost. Also, information on corrosion monitoring methods such as coating survey, chemical analysis, cathodic protection survey, non-destructive test (ultrasonic thickness measurement), intelligent pigging and the cost were obtained (Akinyemi et al., 2012). The frequency of use of each method was also ascertained whether it is daily, weekly, monthly, annually or perennially as shown in Table 1 using chemical treatment involving the use of corrosion inhibitors, scale inhibitors and biocides. $C_{1}$ to $C_{11}$ in Table 2 are cost of corrosion control methods adopted by different companies in the oil and gas sector within the year 2004-2008. The data obtained was analyzed to evaluate the cost on corrosion prevention, monitoring and inspection and maintenance on annual basis, this is shown in Figure 4 and 5 (Akinyemi et al., 2012). This study showed the cost of corrosion control within the year 2004-2008 to be far less compared to the estimated cost of oil spillage in 1978 alone brought about by damaged pipelines which is over $\$ 38$ billion, prevention is really better than cure. No real cost is associated with cleaning pigging as it is 
carried out by maintenance personnel in conjunction with the production personnel on the field at no cost. Cathodic protection was not installed within the years in view.

Table 1. Frequency and cost of chemical treatment of corrosion from 2004-2008 (Akinyemi et al., 2012).

\begin{tabular}{ccc}
\hline Chemical Treatment & Frequency & Cost $\mathbf{( \$ )}$ \\
\hline Scale Inhibitor & Daily & 226,561 \\
\hline Corrosion Inhibitor & Daily & 56,993 \\
\hline Biocides & Monthly & 94,552 \\
\hline Total & & 378,106
\end{tabular}

Table 2. Cost (\$) of Contribution of corrosion prevention, maintenance and monitoring and inspection methods (Akinyemi et al., 2012).

\begin{tabular}{|c|c|c|c|c|c|c|c|c|c|c|c|c|}
\hline \multirow{2}{*}{ Year } & \multicolumn{4}{|c|}{$\begin{array}{c}\text { Corrosion Prevention } \\
(\$)\end{array}$} & \multicolumn{2}{|c|}{$\begin{array}{c}\text { Corrosion } \\
\text { Maintenance (\$) }\end{array}$} & \multicolumn{5}{|c|}{$\begin{array}{c}\text { Corrosion Monitoring and Inspection } \\
\text { Methods (\$) }\end{array}$} & \multirow{2}{*}{ Total } \\
\hline & $\mathrm{C}_{1}$ & $\mathrm{C}_{2}$ & $\mathbf{C}_{3}$ & $\mathrm{C}_{4}$ & $\mathrm{C}_{5}$ & $\mathrm{C}_{6}$ & $\mathbf{C}_{7}$ & $\mathrm{C}_{8}$ & $\mathrm{C}_{9}$ & $\mathrm{C}_{10}$ & $\mathrm{C}_{11}$ & \\
\hline 2004 & & 59,34 & - & - & 16,750 & 28,900 & 2,225 & - & 9,451 & - & - & 116,660 \\
\hline 2005 & 9273 & 53,106 & - & - & 15,580 & 43,800 & 3,210 & - & - & - & - & 124,969 \\
\hline 2006 & 45,836 & 63,849 & - & - & 16,710 & 29,140 & 3,955 & - & - & - & - & 159,490 \\
\hline 2007 & 32,886 & 96,037 & - & - & 21,360 & 24,560 & 4,215 & 108,715 & - & 131,285 & - & 419,058 \\
\hline 2008 & & 105,783 & - & - & 23,260 & 43,568 & 5,742 & - & 49,245 & - & - & 227,598 \\
\hline Total & 87,995 & 378,109 & - & - & 93,950 & 169,968 & 19,347 & 108,715 & 58,696 & 131,283 & - & $1,048,336$ \\
\hline
\end{tabular}

\section{Effects of oil spill as a result of corrosion}

Economic effects: Corrosion has proven to be a headache in the oil and gas sector in Nigeria. Every year, the oil and gas sector in Nigeria incur huge losses due of corrosion. The costs of corrosion and its devastations are staggering. Corrosion has also affected large corporations in their operations. Some companies take effective measures, like using excellent materials and constantly modifying their equipment to prevent corrosion which has obviously improved their growth and productivity (Vortex, 2016).

Technological effects: Corrosion has considerably been an obstacle to many advances in technology in the oil and gas sector in Nigeria. Quite a few advances require materials to withstand high temperatures and highly corrosive environments. The drillings for oil in sea and land have also been deterred due to problems caused by corrosion, which has impeded our progress in the energy sectors. But at the same time, certain measures have been taken to reduce the effects of corrosion. Over time, the technological effects of corrosion will surely be curtailed (Vortex, 2016). 


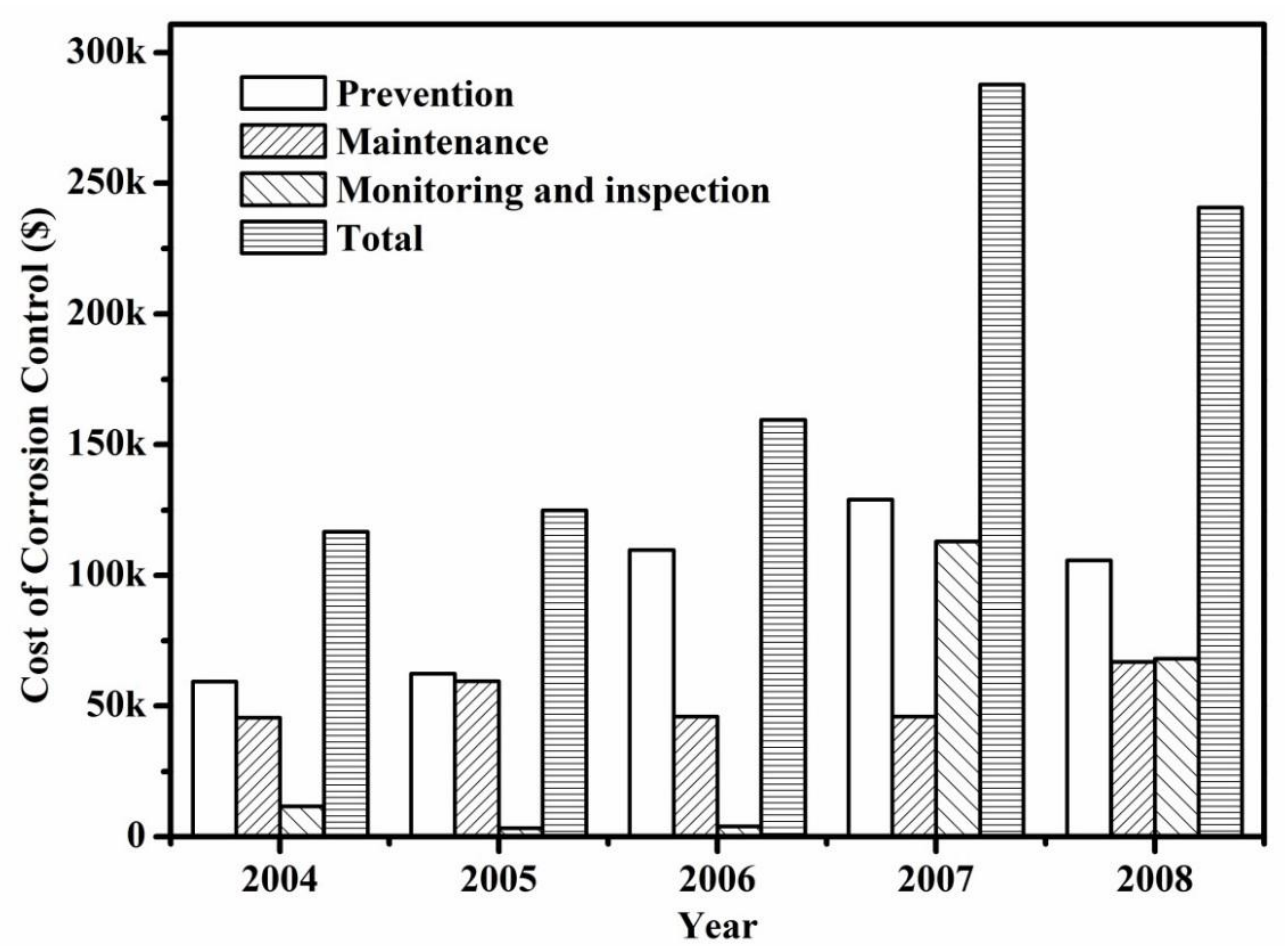

Figure 4. Cost of corrosion control from 2004-2008 (Akinyemi et al., 2012).

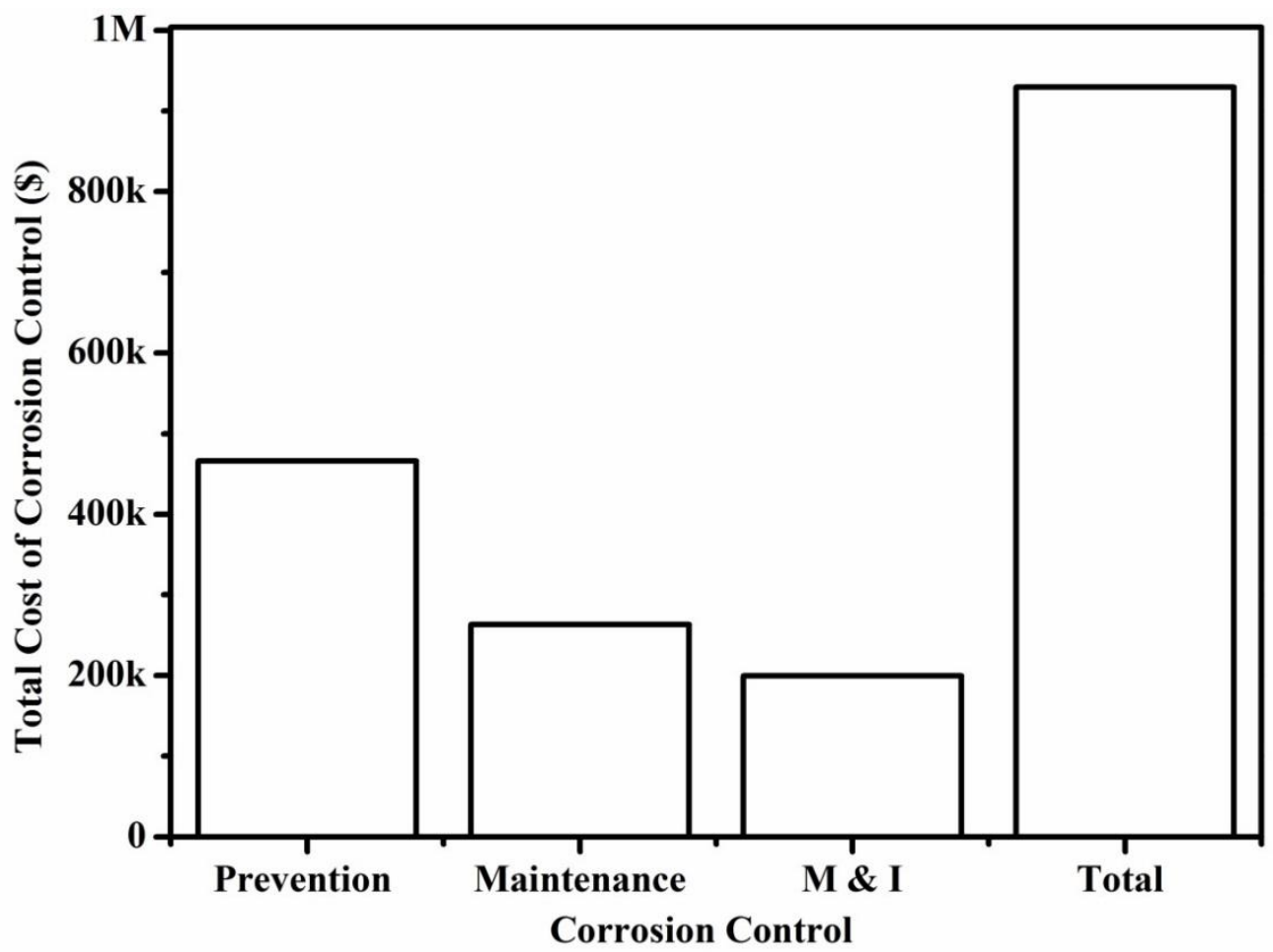

Figure 5. Total cost of corrosion control from 2004-2008 (Akinyemi et al., 2012). 
Safety effects: Structures that cannot sustain their environment can prove to be very dangerous. It can cause serious injuries and even loss of life. Corrosion endangers the safety of our modern-day structures like aircraft, bridges, automobile, pipelines and so on. Governments and responsible authorities must make sure that the effects of corrosion are minimized to ensure the safety of citizens by taking effective corrosion prevention measures. Oil spills have posed a major health risk to the inhabitants of the Niger Delta region. Crude oil contains a variety of poisonous chemicals including nitrogen dioxide $\left(\mathrm{NO}_{2}\right)$, Sulphur dioxide $\left(\mathrm{SO}_{2}\right)$, volatile organic compounds like benzene, toluene, xylene and hydrogen sulfate, as well as carcinogens e.g. benzopyrene, dioxin, etc. Exposure to these substances leads to respiratory disorders, aggravated asthma, chronic bronchitis, cancer, genetic damage and reproductive disorders (Vortex, 2016).

Socio-economic deprivation: Niger Delta region is surrounded by oceans, creeks, and rivers indicating that the inhabitants are mostly professional fishermen. Oil spills emanating as a result of corrosion from the offshore and onshore pipelines annihilate the aquatic environment and render the drinking water sources unfit for consumption. It therefore, deprives the people of their major means of livelihood (fishing). Furthermore, oil spills on land render the soils infertile, leading to reduced crop yield. The resultant effect is hunger and a hostile/hash economic environment (Adindu et al., 2013).

Figure 6-8 shows the effect of oil spill in different parts of the Niger Delta, while Figure 9 shows the effect of corrosion on a pipeline in the Niger Delta.

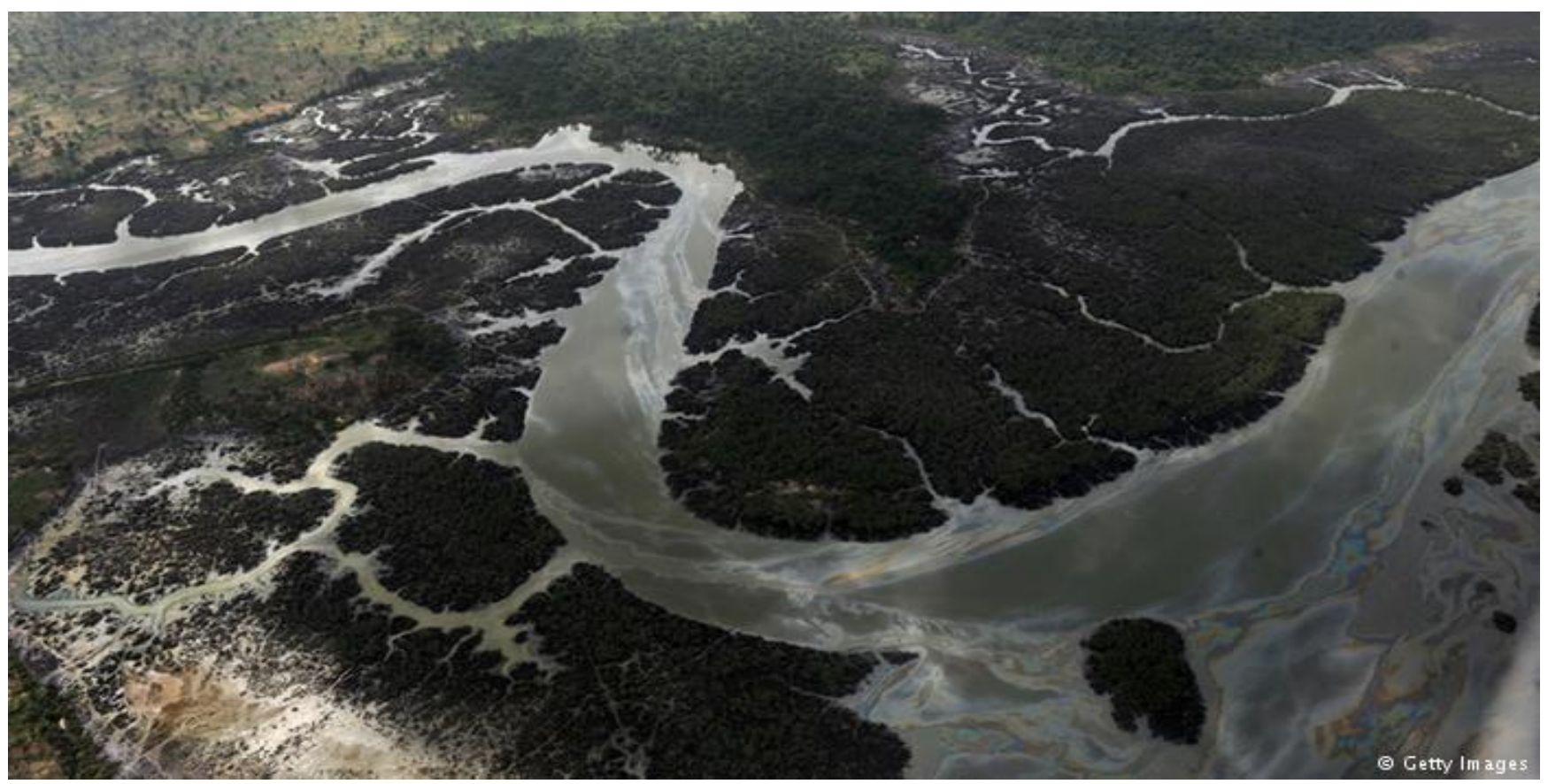

Figure 6. The once-pristine Niger Delta has been polluted for decades. Source: www.dw.com 


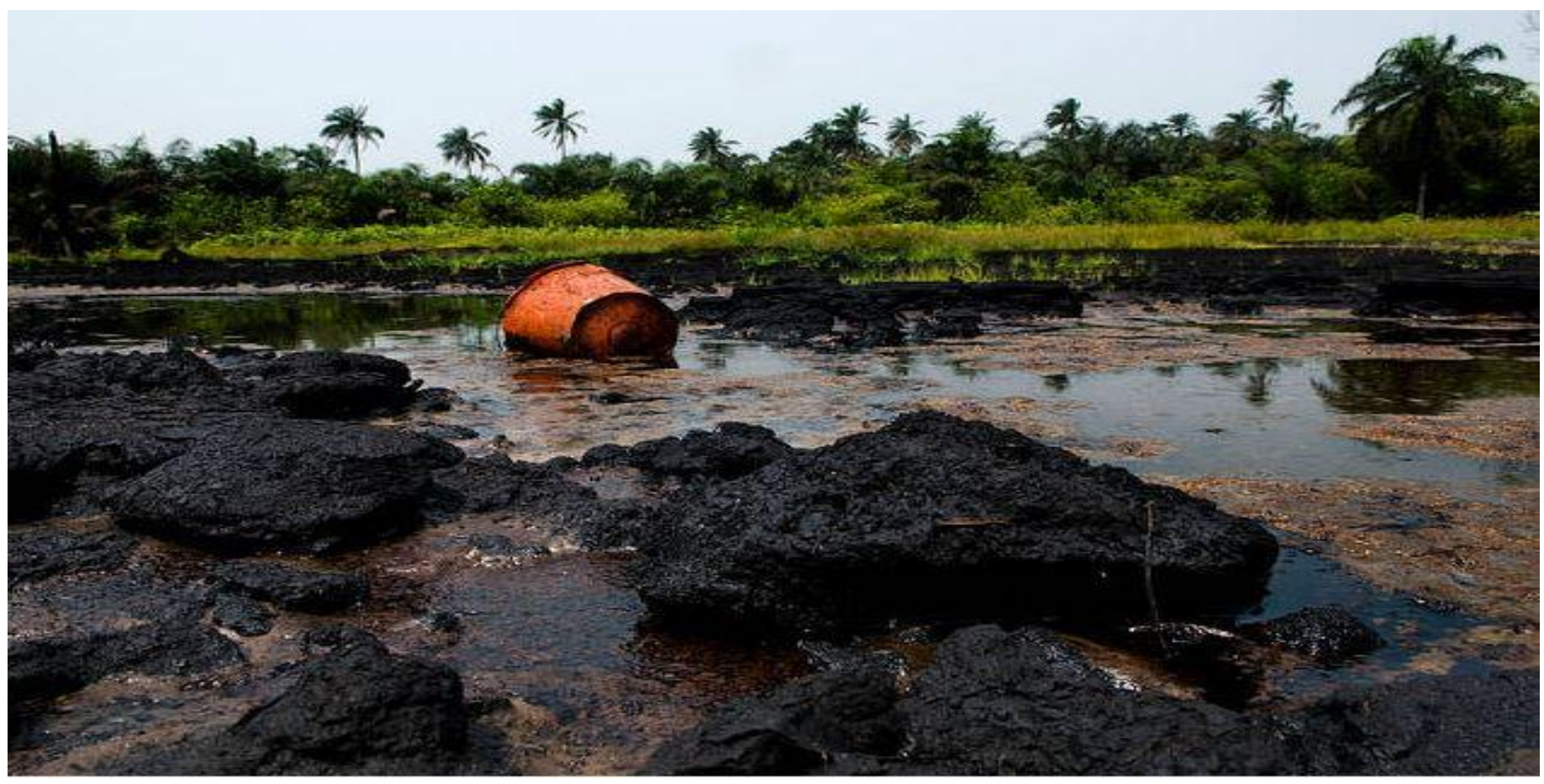

Figure 7. Effect of the oil spill in Kalaba Community in Okordia clan of Yenagoa Local Government Area of Bayelsa State. Source: www.informationng.com

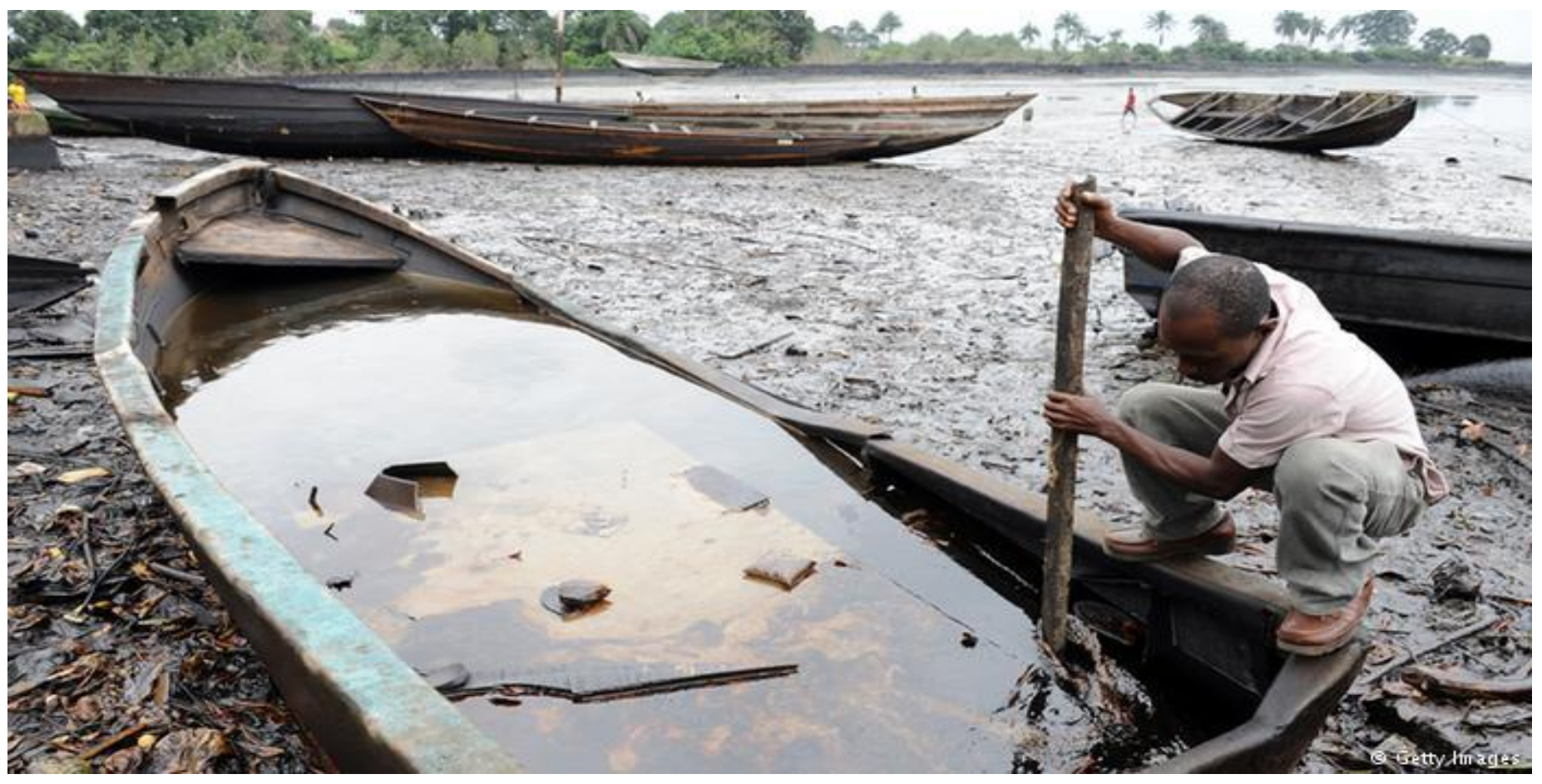

Figure 8. The spill near Bodo left this creek filled with oil, not fish. Source: www.dw.com 


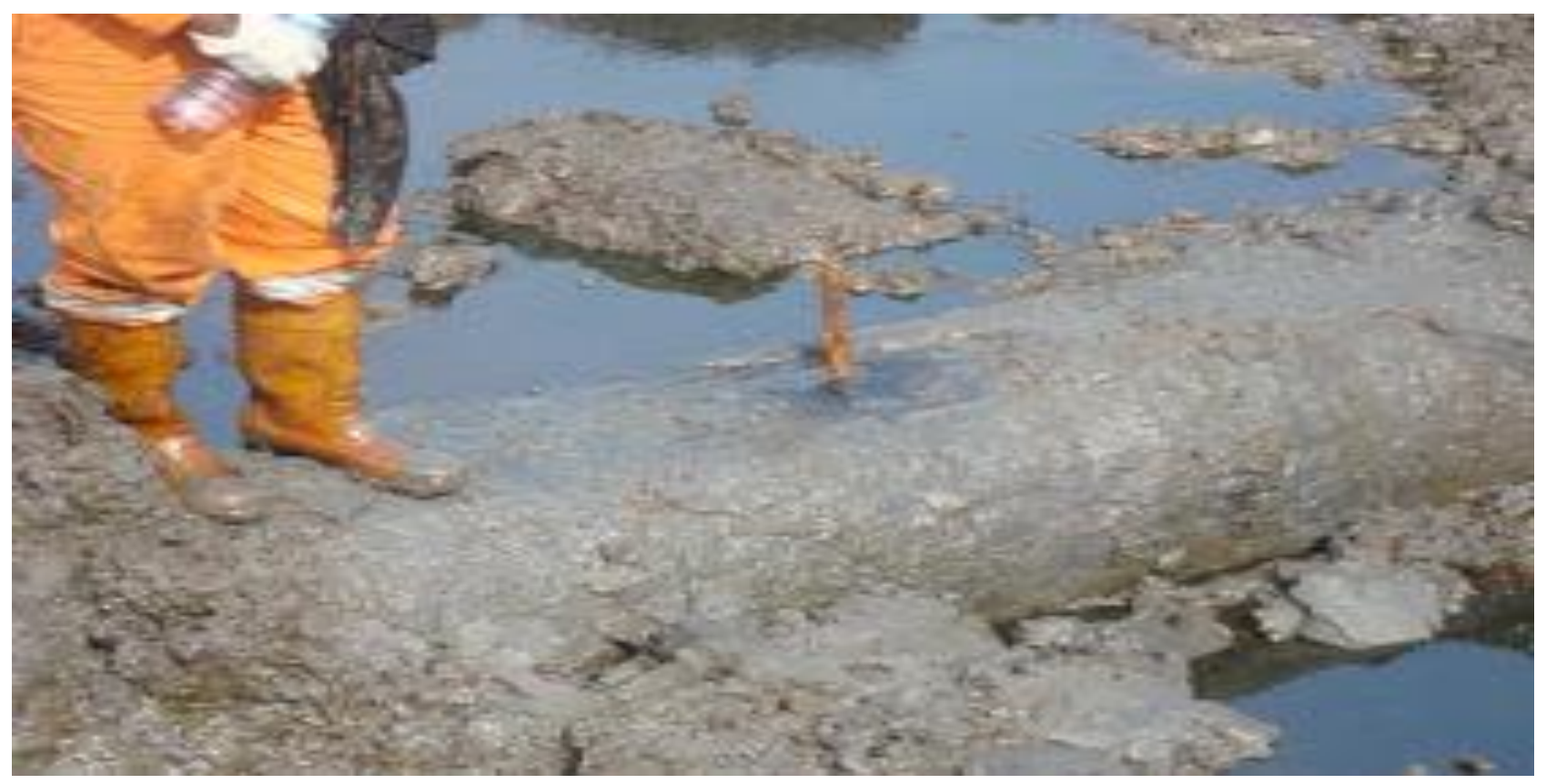

Figure 9. The pipeline after the leak had been stopped (by hammering a stick into the hole), showing apparent corrosion around the leak site. Source: Center for Environment, Human right and development www.sciencythoughts.blogs

\section{The challenges facing the oil and gas sector in Nigeria}

While lack of funding ranks high on the list of concerns for corrosion control programs in the oil and gas industry in Nigeria, there are also challenges related to increased expectations from the public for safety, stricter governmental regulations and, perhaps more than anything, a shortage of experienced personnel (Bradley, 2015). With an aging workforce that is nearing retirement, the National Association of Corrosion Engineers (NACE) provides training for new people entering the oil and gas sector in Nigeria and other countries, but the oil companies would be Flosing a tremendous amount of institutional knowledge if they wave the need for these training in the next few years. Even today, service companies experience challenges recruiting and maintaining experienced technical personnel on corrosion control because having experienced and qualified people is "the most critical part" of a corrosion control program in the oil sector in Nigeria. Companies in the oil sector must continue to train, certify and provide an opportunityfor their corrosion control personnel to ensure the program is being properly maintained (Norsworthy, 2015). Aging infrastructure, particularly as it relates to pipeline coatings, is another major concern in the industry, many companies do not realize that most stress corrosion cracking (SCC) and external corrosion issues with bacteria occur under disbanded cathodic protection (CP) shielding pipeline coatings is as a result of aging. Oil companies in Nigeria have a great challenge maintaining older infrastructure and it can be very difficult obtaining rights of way needed to conduct work on the pipelines, especially in populated areas (Norsworthy, 2015). 


\section{What can be done to save the oil and gas sector in Nigeria from the claws of corrosion?}

The massive costs of corrosion provide many opportunities in the oil and gas sector in Nigeria to manufacturers and suppliers. Opportunities exist to reduce corrosion costs and the risks of failure and to develop new, expanded markets. The costs of corrosion vary considerably from industry to industry. The first step in any cost-reduction program is to identify and quantify the present costs of corrosion. Based on this analysis and a review of the present status of corrosion control in the oil and gas sector, priorities can be determined and the most rewarding cost-reduction projects pursued (Feather, 2015).

The risk of corrosion failure can be lowered in the producer's facility and in the quality of the products. Both process and products can be analyzed to identify the areas where corrosion failures occur. Once identified, the risk of failure can be evaluated from the perspectives of impact on safety, product liability, avoidance of regulation, and loss of goodwill. Where risks are too great, technological changes can be implemented to reduce the risk. The evaluation also can identify areas where technological advances are required in the industry. Through the application of existing or emerging technologies to products or services, advances are being made in all methods for corrosion control: material selection, coatings, inhibitors, cathodic protection, and design. Market opportunities are to be found in the transfer of existing technologies to other industries (Feather, 2015). Corrosion control specialists in Nigeria are charged with protecting and extending the lifecycle of critical infrastructures. For oil and gas pipelines, it is a matter of protecting the public, the quality of the products and as well as the environment. Corrosion is one of the leading causes of pipeline failures in the oil and gas sector in Nigeria, but the right measures to protect these assets can ensure they operate safely, efficiently and profitably. The management of corrosion must be an organizational policy where by protecting assets start with deliberate, carefully considered and planned corrosion control and corrosion management (Feather, 2015). Companies should have a policy statement that clearly addresses the organization's objectives for the corrosion management system, Itis of great importance to ensure that the responsibilities of key personnel fall within their areas of expertise and personnel must constantly keep up with changes in the industry through education, training, hands-on experience and certification (Feather, 2015). Companies in the oil and gas sector in Nigeria should also allocate the appropriate resources, financial and human capacity to their corrosion control planning and maintenance. Cutting corners in these areas puts the pipeline and the organization at risk. However, as the price of oil continues to fall globally, companies now look to cut budgets, which could affect corrosion control (Feather, 2015). While funding is a major challenge for corrosion control programs in Nigeria, most oil companies recognize their importance to maintaining integrity.

Companies should be aware that cutting the corrosion budget might be tempting, but not worth the risk or potential fines. Companies are aware of the need to continue an aggressive corrosion control program in Nigeria. Unfortunately, some oil companies in 
Nigeria tend to cut these programs first, but with the regulatory requirements and the legal consequences, most companies will continue to protect their systems. If there is a need for possible budget cuts in the oil and gas sector in Nigeria, corrosion control should not be part of it. Ensuring a proper design and installation of pipelines as well as developing, implementing and maintaining a proper corrosion control plan can ensure safety as well as protect the environment and provide a high return on investment to the oil companies. However, there's not just one methodology for controlling corrosion of pipelines. Coating, cathodic protection, electrical isolation and proper maintenance all play a role, but a properly installed pipeline coating system is paramount with regards to pipeline life. Rankin (2015) reported that pipeline contractors in Nigeria have to be keenly aware and take proper measures to avoid damage to the pipeline coating systems. Cathodic protection is also critical, as it provides protection to bare or uncoated areas of the pipeline where coating systems have degraded or have been damaged. In addition, proper electrical isolation of the pipeline is important, making pipelines easier to protect. Furthermore, doing advanced design and planning work saves a lot of effort later on. Corrosion control programs must be comprehensive and it should involve the top methods for internal and external corrosion control. Monitoring with the use of in-line inspection (ILI) equipment is a valuable asset and should be adopted, as well as Electro Magnetic Acoustic Transducer (EMAT) tools. The EMAT was developed to find small cracks that lead to failure. EMAT technology would allow the company to be proactive instead of reactive to corrosion problems caused by disbanded coatings (Norsworthy, 2105). Government regulations, while perhaps unpopular, serve as a safeguard for ensuring that pipeline infrastructures are protected from corrosion in Nigeria. The government in Nigeria can ensure that legislation and regulations relevant to the industry include language that supports proper corrosion control planning and the use of qualified personnel. NACE International is at the forefront of this issue, with staff monitoring legislation and visiting legislators to inform them of the importance of corrosion control. But some companies might complain about stricter regulations, this explains that these laws are put in place because companies were not doing what is needed to be done. If the various oil companies meet or exceed the regulatory requirements, they end up saving a considerable amount of money by taking care of their resources which reduces leaks, corrosion and improves the public image of the oil sector in Nigeria globally. Pipeline corrosion control starts with the proper design and installation of the infrastructure. Oil companies in Nigeria should take the time to develop, implement and maintain a proper program, these assets will operate safely while protecting the environment and providing a profitable system to the owner. "This is a win-win for everyone." (Feather, 2015).

\section{Conclusion}

Corrosion is a probabilistic phenomenon that requires interdisciplinary expertise that incorporates surface science, metallurgy/material science, electrochemistry, thermodynamics, kinetics, mechanics, hydrodynamics and chemistry. Corrosion has been a major problem for over half a decade in the oil and gas industry in Nigeria, and only with proper 
maintenance and management would the oil and gas industry be able to save billions of naira which have been lost. Adoptable strategies on how to effectively manage corrosion hav been reviewed and if adhered to, would not only reduce the loss of funds spent annually on corrosion treatment but also help improve the quantity and quality of petroleum products yield annually. But corrosion is a world problem not only restricted to Nigeria, therefore, its solution is essential as it covers many areas of our daily needs. However, the principles and chemistry of corrosion must be comprehended consciously by corrosion specialist in order to effectively select materials and metals structures for the optimum economic life of facilities and safety in oil and gas operations. Also, it should be clearly understood that no particular material is the ultimate cure for the damages of corrosion but a means to an end.

\section{Recommendation}

Employing corrosion control programs will extend the life cycle of pipelines in Nigeria, but its best if done early. Implementing corrosion control at any point in the life of these pipeline systems and other components fitting can help extend the life, and quality of the product. But early use of corrosion control technology, specified and implemented by qualified corrosion professionals, can extend the life of infrastructure and reduce costs over the life of the infrastructure.

\section{References}

1. C.H. Achebe, U.C. Nneke and O.E. Anisiji, Analysis of Oil Pipeline Failures in the Oil and Gas Industries in the Niger Delta Area of Nigeria, Proceedings of the International Multi-Conference of Engineers and Computer Scientists, 2012, 2, March 14-16, Hong Kong.

2. C.I. Adindu, F.A. Oduagwu and S.I. Okeahialam, Management of oil Spill due to Pipeline corrosion in the Niger Delta region of Nigeria, www.researchgate.net/publication/306356390, 2013 (Accessed April 2, 2018).

3. O.O. Akinyemi, C.N. Nwaokocha and A.O. Adesanya, Evaluation of corrosion cost of crude oil processing, Eng. Sci. Technol., 2012, 7, no. 4, 517-528.

4. K. Bradley, Corrosion control industry faces challenges to protect oil and gas Infrastructure, http://napipelines.com/corrosion-control-industry-oil-gas-infrastructure 2015 (Accessed April 2, 2018).

5. Shell and the N15bn Oil Spill Judgment Debt, Lagos, Nigeria, Daily Independent Newspaper, 2010, July 19.

6. J. Feather, Corrosion control industry faces challenges to protect oil and Gas Infrastructure, http://napipelines.com/corrosion-control-industry-oil-gas-infrastructure, 2015 (Accessed April 2, 2018).

7. P. Hopkins, Learning from Pipeline Failures, WTIA/APIA Welded Pipeline Symposium, Perth, Australia, March 2008. 
8. N.O. Isirimah, A.C. Chinda and S.A. Braide, Environmental protection: problems, progress, practice and prospects: case for Niger Delta, paper presented at the Nigeria Environmental Society Monthly Seminar Series, Amphitheatre Rivers, State University of Science and Technology, Port Harcourt, May 10, 2006.

9. K. Kalejaye, http://sweetcrudereports.com/2015/09/02/nigeria-records-9343-oil-spillincidents-in-10-years, 2015 (Accessed April 2, 2018).

10. M.B. Kermani and D. Harrop, The impact of corrosion on oil and gas industry, Soc. Pet. Eng., 1996, 11, no. 3, 186-190.

11. P.C. Nwilo, K.O. Peters and O.T. Bodeji, Sustainable management of oil spill incidents along the Nigerian coastal areas, paper presented at Electronic Conference on Sustainable Development Information Systems, CEDARE, Taipei, 2000.

12. P.C. Nwilo and O.T. Badejo, Impacts of oil spill pollution along the Nigerian coastal areas soil sediment and water, The Association for Environmental Health and Sciences, 2001.

13. P.C. Nwilo and O.T. Badejo, https://nigerdeltatoday.wordpress.com/2008/10/24/ mpacts-of-oil-spills-along-the-Nigerian-coast 2008 (Accessed April 2, 2018).

14. R. Norsworthy, Corrosion control industry faces challenges to protect oil and gas Infrastructure, http://napipelines.com/corrosion-control-industry-oil-gas-infrastructure 2015 (Accessed April 2, 2018).

15. C.I. Ozumba, Sabotage and corrosion spills in SPDC-W, 1987-1996, National Association of Petroleum Explorationists (NAPE) Bulletin, 1997, 13, no. 1, 3-49.

16. D. Rankins, Corrosion control industry faces challenges to protect oil and gas Infrastructure, http://napipelines.com/corrosion-control-industry-oil-gas-infrastructure, 2015 (Accessed April 2, 2018).

17. UNDP (2006), Niger delta human development report, p. 76.

18. C. Umezurike, Combating oil spillage with chemical dispersants, NICA, Proceedings of $2^{\text {nd }}$ International Corrosion Conference, Abuja, Nigeria, 1999.

19. U. Unueroh, G. Omonria, O. Efosa and M. Awotunde, Pipeline corrosion control in oil and gas industry: a case study of NNPC/PPMC system 2A pipeline, Nigerian J. Technol., 2016, 35, 317-320.

20. J. Vidal, Nigeria's agony dwarfs the gulf oil spill, the US and Europe ignore it, www.theguardian.com/world/2010/may/30/oil-spills-nigeria-niger-delta-shell, $\quad 2010$ (Accessed April 2, 2018).

21. Vortex, Effects of corrosion, http://www.vortexenergysaver.com/tag/prevent-corrosion 2016 (Accessed April 2, 2018).

22. World oil online, www.worldoil.com/magazine/2012 (Accessed April 2, 2018).

23. www.dw.com/en/oil-spills-keep-devastating-niger -delta/a-18327732 (Accessed April 2, 2018).

24. www.informationng.com/2016/09/oil-spills-throw-bayelsa-community-into-panic.html (Accessed April 2, 2018). 
25. www.sciencythoughts.blogspot.co.ke/2012/08/amnesty-international-reports-on2012.html?m=1 (Accessed April 2, 2018).

\section{Appendix}

Table 1. Oil spill corrosion related incidents from 1976-1999 (Nwilo and Badejo, 2008).

\begin{tabular}{cccccc}
\hline Year & $\begin{array}{c}\text { Number of } \\
\text { Incidents }\end{array}$ & $\begin{array}{c}\text { Percentage } \\
\text { number of } \\
\text { incidents per total } \\
\text { incidents (\%) }\end{array}$ & $\begin{array}{c}\text { Volume } \\
\text { spilled } \\
\text { (Barrels) }\end{array}$ & $\begin{array}{c}\text { Percentage } \\
\text { volume spilled } \\
\text { per total } \\
\text { volume (\%) }\end{array}$ & $\begin{array}{c}\text { Estimated } \\
\text { worth in } \\
\text { Dollars (\$) }\end{array}$ \\
\hline 1976 & 128 & 2.20 & 26157 & 1.03 & $2,082,620$ \\
1977 & 104 & 1.79 & 32880 & 1.29 & $2,617,846$ \\
1978 & 154 & 2.64 & 489295 & 19.23 & $38,957,648$ \\
1979 & 157 & 2.70 & 694117 & 27.28 & $55,265,606$ \\
1980 & 241 & 4.14 & 600511 & 23.60 & $47,812,687$ \\
\hline
\end{tabular}

Table 2. Oil spill corrosion incidents from 2000-2011 (Adindu et al., 2013).

\begin{tabular}{cccccc}
\hline Year & $\begin{array}{c}\text { Number of } \\
\text { Incidents }\end{array}$ & $\begin{array}{c}\text { Percentage } \\
\text { number of } \\
\text { incidents per total } \\
\text { incidents } \mathbf{\%})\end{array}$ & $\begin{array}{c}\text { Volume } \\
\text { spilled } \\
\text { (Barrels) }\end{array}$ & $\begin{array}{c}\text { Percentage } \\
\text { volume spilled } \\
\text { per total } \\
\text { volume (\%) }\end{array}$ & $\begin{array}{c}\text { Estimated } \\
\text { worth in } \\
\text { Dollars } \mathbf{( \$ )}\end{array}$ \\
\hline 1981 & 238 & 4.09 & 42723 & 1.68 & $3,401,566$ \\
1982 & 257 & 4.41 & 42841 & 1.68 & $3,411,000$ \\
1983 & 173 & 2.97 & 48351 & 1.90 & $3,849,731$ \\
1984 & 151 & 2.59 & 40209 & 1.58 & $3,201,441$ \\
1985 & 187 & 3.21 & 11876 & 0.47 & 945,615 \\
1986 & 155 & 2.66 & 12905 & 0.51 & $1,027,496$ \\
1987 & 129 & 2.21 & 31866 & 1.25 & $2,537,171$ \\
1988 & 208 & 3.57 & 9172 & 0.36 & 730,275 \\
1989 & 195 & 3.35 & 7628 & 0.30 & 607,354 \\
1990 & 160 & 2.75 & 14941 & 0.59 & $1,189,588$ \\
1991 & 201 & 3.45 & 106828 & 4.20 & $8,505,644$ \\
1992 & 367 & 6.30 & 51132 & 2.01 & $4,071,123$ \\
1993 & 428 & 7.35 & 9752 & 0.38 & 776,472 \\
1994 & 515 & 8.84 & 30283 & 1.19 & $2,411,106$ \\
1995 & 417 & 7.16 & 63677 & 2.50 & $5,069,976$
\end{tabular}




\begin{tabular}{cccccc}
\hline Year & $\begin{array}{c}\text { Number of } \\
\text { Incidents }\end{array}$ & $\begin{array}{c}\text { Percentage } \\
\text { number of } \\
\text { incidents per total } \\
\text { incidents (\%) }\end{array}$ & $\begin{array}{c}\text { Volume } \\
\text { spilled } \\
\text { (Barrels) }\end{array}$ & $\begin{array}{c}\text { Percentage } \\
\text { volume spilled } \\
\text { per total } \\
\text { volume (\%) }\end{array}$ & $\begin{array}{c}\text { Estimated } \\
\text { worth in } \\
\text { Dollars (\$) }\end{array}$ \\
\hline 1996 & 430 & 7.38 & 46353 & 1.82 & $3,690,635$ \\
1997 & 339 & 5.82 & 59272 & 2.33 & $4,719,261$ \\
1998 & 390 & 6.70 & 9845 & 0.39 & 783,859 \\
1999 & 100 & 1.72 & 62121 & 2.44 & $4,946,100$ \\
2000 & 84 & 5.47 & 34000 & 5.97 & $2,707,080$ \\
2001 & 72 & 4.69 & 12000 & 2.11 & 955,440 \\
2002 & 70 & 4.56 & 21500 & 3.78 & $1,711,830$ \\
2003 & 59 & 3.84 & 50350 & 8.84 & $4,008,867$ \\
2004 & 116 & 7.56 & 47000 & 8.25 & $3,742,140$ \\
2005 & 108 & 7.04 & 95200 & 16.72 & $7,579,824$ \\
2006 & 90 & 5.86 & 28450 & 5.00 & $2,265,189$ \\
2007 & 250 & 16.29 & 35000 & 6.15 & $2,786.700$ \\
2008 & 162 & 10.55 & 100420 & 17.63 & $7,995,440$ \\
2009 & 141 & 9.19 & 105200 & 18.47 & $8,376,024$ \\
2010 & 183 & 11.92 & 25000 & 4.39 & $1,990,500$ \\
2011 & 200 & 13.03 & 15400 & 2.70 & $1,226,148$ \\
\hline Total & $\mathbf{5 , 8 2 4}$ & $\mathbf{1 0 0 . 0 0}$ & $\mathbf{2 , 5 4 4 , 7 3 5}$ & $\mathbf{1 0 0 . 0 0}$ & $\mathbf{2 0 2 , 6 1 1 , 8 1 8}$ \\
\hline & & & & & \\
\hline
\end{tabular}

Table 3. Total cost of corrosion control (\$) from 2004-2008 (Akinyemi et al., 2012).

\begin{tabular}{ccccc}
\hline Year & Prevention (\$) & Maintenance (\$) & $\begin{array}{c}\text { Monitoring and } \\
\text { inspection (\$) }\end{array}$ & Total (\$) \\
\hline 2004 & 59,334 & 45,650 & 11,676 & 116,658 \\
2005 & 62,379 & 59,380 & 3,210 & 124,969 \\
2006 & 109,685 & 45,850 & 3,955 & 159,490 \\
2007 & 128,923 & 45,920 & 112,930 & 287,773 \\
2008 & 105,783 & 66,828 & 68,112 & 240,723 \\
\hline Total & 466,104 & 263,628 & 199,883 & 929,613 \\
\hline
\end{tabular}

